\title{
Varieties of English Language in Nigeria: A Tool for Character Stratification in Wole Soyinka's The Beatification of Area Boy.
}

\author{
Olagunju Robert Modupeola \\ (General Studies Department, Osun State Polytechnic,Iree, Nigeria)
}

\begin{abstract}
Language is not only a means of communication; rather it has served man in diverse ways. Wole Soyinka in his The Beatification of Area Boy has shown another role language can play in drama. It is a means of showing the various class statuses of characters in a dramatic setting. Since drama expresses the social realities of a society, the playwright has been able to bring to fore the contemporary role English language has been playing in the linguistic setting of Nigeria. Wole Soyinka, has been able to show that the language is not confined to people of a particular educational background but it is a language that everyone has been able to manipulate and found useful for communicative purposes. Thus, the varieties of English identified in The Beatification of Area Boy shows the social stratification of people in a typical Nigerian society which resulted from the different educational background of each character.
\end{abstract}

\section{Introduction}

Drama represents life in a distinct way. It is said to be a mirror of life. It is a unique genre in the sense that it draws its raw materials directly from life (human activity) and uses them as its medium of expression; as such it is said to be an imitation of life. In this sense it is said to be drawn to human life than other human expressions.

Language use in drama has shown the dexterity displayed by playwrights in manipulating language to serve dramatic ends. This demonstrates the appropriate use of language as a vehicle of characterization. Raymond Chapman $^{1}$ (1982) opines that dialogue must not only show the traits of a character, but also the characters' response to them and their situation. Drama in whatever form it is rendered, either spoken or written is an offshoot of the playwright's socio-cultural background, personality and the degree of his expression to life.

To most African playwrights, language is an instrument employed to portray their characters' social class, age and background; notable examples are Ola Rotimi, Wole Soyinka, Femi Osofisan and Olu Obafemi. To such playwrights who use the medium of English, the different shades of English existing in a community are a veritable tool for character identification. Tony Obilade (1993) affirms this when he says "In Achebe and Soyinka PE (Pidgin English) is made for humour as well as for character portrayal. All these manifest in their work and they dominate other features in term of aesthetics, creativity and life.

As a successful playwright, Wole Soyinka ${ }^{3}$ paints a panoramic picture of the strings of problems in the society caused by lack of vision of Nigerians and indeed African leaders and inspires the people with the hope that a concerted effort can bring an end to these problems. This he did through language. The play under review is a comedy that satirizes the society and make for ways to bring transformation.

\section{The Beatification Of Area Boy}

The setting of the play is the city centre. The play is located in front of an opulent shopping plaza in the city of Lagos. The city centre is home to a wide array of characters who have come together to earn a living. It is more attractive again to the affluent ruling classes who have also come to hold a society wedding at the plaza. This is why the cast of the play consists of the high and the low classes. The names of actors reflects this Trader, Barber, Boyko, Sanda, Mama Put, Cyclist Miseyi, conductor, Big Man Shopper Military Officer etc.

The play is a comedy that satirises the society both politically and socially. It revolves round its major character, Sanda, a security guard for the shopping plaza who holds the seeming chaotic nature of the play together in unity. He is the brain behind all the racketeering that goes on in the area in question. Other members of the gang include Boyko - the destitute boy, Trader (Area two-one), Are two-four, Barber and several others, who execute Sanda's hideous plans. Barber peddles the superstitions story of people rising into wealth through cutting human pants for ritual activities. His story seems to be corroborated when the case of an alleged missing genital comes on stage. Though the accused has not been proved guilty, there is a ready crowd to lynch him. The dearth of means of transportation causes commotion and struggle for the few available buses. This results in the trampling on of a passenger's baby. 
Prisoners who are meant to emerge reformed are brought to clean the city centre for the great wedding that attracts the affluent in the society. While the poor such as Minstrel and Boyko looks forward to it for their own windfall.

Miseyi, the prospective bride happens to be Sanda's schoolmate. They meet and she later discovers she does not belong to the affluent class. At the wedding, she commits class suicide; rather than choose the expected bridegroom, she runs up to Sanda and this leads to confusion. This brings division between the people; the rich and the affluent on one side and Sanda and others on the other side. The affluent employs the army and the police to route the poor while Sanda put his strategy together to protect his people.

\section{The English Language Situation In Nigeria}

Commercial activities of the English and Portuguese traders along the West African coast around the $16^{\text {th }}$ century brought about the implantation of English language into Nigeria (Banjo ${ }^{4}, 1996$; Jolayemi ${ }^{5}, 2013$ ). There arose the need to break the communication barrier that existed between the European traders and the natives at the coast. This necessitated the need to teach the basic English for communication, business transaction, and missionary activities and for other official activities. It is therefore evident that the main reason for the introduction of the language into the west coast was for communicative purposes since the traders themselves were not willing to learn indigenous languages. English thus has to be imposed and taught to train needed hands as clerks, interpreters, stewards, messengers e.t.c to assist in the administrative aspect of their trade.

The multilingual situation of Nigeria with over three hundred and fifty languages (Adegbite and Akindele $^{6}$ 1993) gave an impetus to the spread of English language as the language became a tool of communication between peoples in the country. The wide acceptance of the language has resulted in a situation where it has not only become the mother tongue of many Nigerian children (Adeyanju 2009,Ogunsanya 2009 in Jolayemi $^{5}$,2013) but English language has made a great influence on the various indigenous languages in Nigeria such that the linguistic interference has brought about an increase in number of vocabulary in the indigenous languages such as in Yoruba of the south western part of Nigeria where we have such words as 'titi' .(street), 'kobo'(penny), 'loya'(lawyer), 'telo'(tailor), 'jiga'(jigger),'idoti' (dirty),'palo' (parlour) e.t.c. Also the incidences of code mixing and code switching have also resulted into various varieties of English language. These varieties of English language that can be identified include: Standard English, Nigerian Standard English, Pidgin English and the Interference variety.

Analysis

The episodes in this study are some of the nefarious activities perpetrated by the gang which Sanda controls. The first has to do with a foreigner who had been ripped off because he did not understand the process for payment of parking fees. While the second has to do with the Big Man Shopper whose car had been burgled and he holds Boyko responsible. In this episodes, four shades of English varieties in use in Nigeria are identified; World Standard variety; as spoken by the foreigner; Nigerian Standard variety as spoken by Big Man Shopper, Sanda and others in the text such as Barber, Miseyi, the military officer and the Thugs; Interference variety, as spoken by Boyko, Prisoner 1, the Bus Conductor and Barber. While the Pidgin variety is spoken by Sanda, Trader, Barber, Mama-Put, Parking attendant and the Prisoner. Except for foreigner, Big Man Shopper and Miseyi who were rigid in the choice of variety of English spoken, choices of variety of English spoken is dependent on the social status of characters being spoken to.

In the dialogue involving foreigner, Sanda, Parking Attendant and Trader; the foreigner and Sanda exhibits an effective knowledge of the World Standard English which is free of any mother-tongue interference. Foreigner. What sort of a swindle is this?

It's a bloody racket and you're all in on it.

Sanda

You were given the discounted rate for foreigners. Normally

It's ten naira for Comprehensive Insurance, five for Third Party.

While the Parking Attendant and Trader speak the variety which is at variant with the World Standard variety - Statements 11 and 31 are examples:

Parking Attendant: Which kin' pay?

Show me your receipt

The elision of the last letter in 'kind' which is expressed with an apostrophe is a regular phonological feature of the Nigerian Pidgin. Other examples like this abound.

Trader..... I wan' think small p.7 'want'

Trader..... It mus' to help... p.9 'must'

Passenger's voice. No, lef' me, lef' me make I die p.58 'leave' There may also be the elision of an entire word in a statement.

Trader.... and you begin “cry like women - 'to' is omitted in this statement.

Statement 31 
Trader. Wetin dis man dey talk about'

You no get protection racket for your country. Abi na to your Europe dem place, and America dey come perfect protection and Mafia and wetin else? De Nigerians wey den kill for

America dis last year alone, e pass twelve, all because they refuse pay protection money. Some na simple taxi driver, one wey dem report for paper only last week, 'e just dey push ice - cream bicycle. Dem shoot am to death because 'e refuse to pay... p.40

Wetin is an example of the collapsing of elements of two word structures - what is'. Two normal lexical items are brought together to form a word.

This is a regular feature in the Nigeria Pidgin. Other structures like this abound.

Trader:... just siddon dere dey read book and magazine p.65

Prisoner $1: . .$. I get siddon chop

Siddon is realized from 'sit down'.

Conductor: Anybody wey no comot for step p.56

Trader: Comot my friend! p.42

Comot is a collapsed form of 'Come out'

Phonological features are relatively difficult to highlight in writing. What writers do is to alter this usual spelling of a word in order to give an indication of a change in a pronunciation context. Pidgin is most distinct as a variety of English at the phonological level so lexical items such as Dis, Dat, Dese, De, Dere are a result of phonological distortion of the Standard English. The voiced alveolar plosive / d / is used to replace the voiced dental fricative / $~ /$ as such:

Dis as in / d / replaces [вis ] this
De as in / d / replaces [бi:] the
Dat as in / d / replaces [вæt] that
Dese as in / d / replaces [вi:z] these
Dere as in / d / replaces [вer] there

All these are results of the mother-tongue influence on the speakers of pidgin. As such, statements like;

Pidgin: As such, statements like;

Trader: Wetin dis man ...

Trader: ... I used small time to put new price for all dese goods

'Dey' is used as a modal auxiliary in 'Wetin come dey worry all you people' p.26.

'I dey come.

The use of lexical items which express a different meaning from the original is also paramount in this variety.

Sanda....manure to spread along the ground p.44

...will think that bread is without limit p.45.

Other items like Dash, Kola, bread, wetin-you-carry p.40 stands for bribe in this context. Bread may also mean money in another context.

Two-four. Bread no plenty.

Words which are semantically different are used interchangeably.

Army and soldier; security and guards as in

Big Man Shopper ... and let the soldiers deal with him

Sanda. The army sir? p.42

Direct culture specific expressions are also brought into variety.

Sanda. Someone old enough to be your father is talking and you keep putting mouth in his. p.42

The second clause '.. you keep putting your mouth in his'

Is an expression which is a direct lifting from the Yoruba language.

In the identification of the different varieties of English language usages in the play, Soyinka has been able to stratify his characters into four different classes:

(a) Standard English- Foreigner and Sanda

(b) Nigerian Standard English- Sanda, Big Man Shopper, Miseyi and Barber

(c) Pidgin English - Parking Attendant, Trader, Sanda and Mama-Put.

(d) Interference Variety - Boyko, Prisoner 1, Bus Conductor and Barber.

These divisions show the social class realities in the society- Sanda is the only character that is able to move within these divisions and this is as a result of the fact that while he had gone to school, the reality of his situation has made it possible for him to adapt himself to all classes. Thus the situation in which he finds himself dictates the variety to be employed.

The identification of this division of characters into different classes is an important element in the study of characterisation for pedagogical purposes. Wole Soyinka in The Beatification of 
Area Boy has been able to demonstrate that sociological situation of a play setting such as we have in Nigeria can be a veritable tool of character stratification in Drama.

\section{References}

[1]. R. Chapman. (1982) The Language of English Literature, London. Edward Arnold (Publications)

[2]. T. Obilade (1993) The Stylistic Function of Pidgin English in African

[3]. Literature: Achebe and Soyinka in Research in Wole Soyinka (ed) James Gibbs and Berath Lindfor. African World Press Inc.

[4]. W. Soyinka. (1995) The Beatification of Area Boy: A Lagosian Kaleidoscope, Ibadan: Spectrum Books. Banjo (1996) Making a Virtue of Necessity: An Overview of the English Language in Nigeria, Ibadan, University Press.

[5]. D. Jolayemi (2013) Shifting Grounds to Widen Horizon: Implication for 21st Century Researchers and Teachers of

[6]. English. A Paper presented at the International Conference of National Association of Researchers and Teachers of English as a

[7]. Second Language (NATRESL), Elizade University, Ilara-Mokin, Ondo State, Nigeria 1-14th September.

[8]. W.Adegbite, and F. Akindele. (1993) The Sociology and Politics of English Language in Nigeria: An Introduction, Ile-Ife OAU Press. Bamgbose (1995) English in the Nigerian Environment in Bamgbose, A, Banjo, A, Thomas A (eds) New Englishes: A West African Perspective, Ibadan. Mosuro Publishers and Bookshops.

[9]. R.M.Olagunju. (2005) A Stylistic Study of Wole Soyinka's The Beatification of Area Boy. OAU, Ile-Ife M.A Thesis. 